\title{
Article \\ Historical GIS as a Tool for Monitoring, Preserving and Planning Forest Landscape: A Case Study in a Mediterranean Region
}

\author{
Giuseppe Cillis*(D), Dina Statuto $(\mathbb{D})$ and Pietro Picuno $(\mathbb{D}$
}

SAFE School of Agricultural, Forest, Food and Environmental Sciences, University of Basilicata, Viale Ateneo Lucano, 10, 85100 Potenza, Italy; dina.statuto@unibas.it (D.S.); pietro.picuno@unibas.it (P.P.)

* Correspondence: giuseppe.cillis@unibas.it

Citation: Cillis, G.; Statuto, D.;

Picuno, P. Historical GIS as a Tool for Monitoring, Preserving and Planning Forest Landscape: A Case Study in a Mediterranean Region. Land 2021, 10, 851. https://doi.org/10.3390/ land 10080851

Academic Editor: Theo van der Sluis

Received: 25 July 2021

Accepted: 11 August 2021

Published: 14 August 2021

Publisher's Note: MDPI stays neutral with regard to jurisdictional claims in published maps and institutional affiliations.

Copyright: (c) 2021 by the authors. Licensee MDPI, Basel, Switzerland. This article is an open access article distributed under the terms and conditions of the Creative Commons Attribution (CC BY) license (https:/ / creativecommons.org/licenses/by/ $4.0 /)$.

\begin{abstract}
In order to assess the dynamics of forests and the effectiveness of their management strategies, it is necessary to develop monitoring systems based on qualitative and quantitative tools for their conservation, valorization and restoration. This approach is particularly important for areas that have undergone intense anthropogenic transformations in the last century. In order to do this, it is first necessary to apply a chronological methodology based on historical GIS that allows the integration of different types of geodata. As a result of constantly evolving spatial analysis tools, the monitoring of landscape forest evolution is increasingly more effective and complete. Using as a case study a region representative of common processes of other Mediterranean areas (Southern Italy-Basilicata region), a diachronic analysis of 156 years was applied to evaluate the forest landscape dynamics. Starting from historical cartographies to remotely sensed data available online, a GIS-based approach was implemented to evaluate the spatial and statistical variations of the forest landscape. In this way, it was possible to assess how much, where and how the forest landscape has changed in order to provide a methodology to support more detailed and sectoral studies.
\end{abstract}

Keywords: GIS; FoSS; historical cartography; thematic map classification; Mediterranean forest; Basilicata region; Southern Italy; forest landscape

\section{Introduction}

Several environmental objectives of paramount importance (including mitigation of greenhouse effect and climate change) need to be tackled by increasing the resilience of agroforestry systems, enhancing the rural landscape and improving ecological networks and landscape planning [1]. The transformations of the territory, at different scales, are taking place at an increasing speed due to socioeconomic and climatic dynamics that are determining not only an alteration of ecosystems but also of whole forestry landscapes. These processes are very intense, especially in the Mediterranean regions [2,3] in which the relations between man and the surrounding environment are extremely complex and varied given the relationship between urban/rural and its millennial history [4]. The differences of transformations, in intensity, speed and pattern, depend largely on land characteristics. In fact, in flat areas close to urban and industrial centres, the phenomenon of soil consumption and therefore high rates of soil sealing to the detriment of other types of land cover needs to be considered [5].

Instead, towards inland areas, where hilly and mountainous areas become more prevalent [6,7], the dynamics of transformation are related to changes in land use, a process that has always characterized territories and landscapes, but in recent decades is occurring at accelerating rates and leading to upsets in the ecosystem balance of habitats and soil biogeochemical cycles [8]. Moreover, this is also compromising the landscapes that are historically and culturally linked to traditional agricultural activities that have designed 
and shaped the territory, creating patterns of high ecological interest and resilience to climate change recognized worldwide (UNESCO) [9-11].

These varied dynamics of land use and land cover changes in mountain and hill areas are mainly related to the process of abandonment of land and agricultural activities in less profitable areas due to different causes [12-14]. In fact, there is a strong long-term influence on forests and forest landscapes, as it modifies their ecosystemic structures, conformations and spatial configurations. If in the past, forests were reshaped by forestry and removed to make room for crops, pastures and settlements, now the reverse process is occurring [15].

In particular, especially in the last century, in the hilly and mountainous Mediterranean landscapes, there has been an increasing reduction of human activity [16], especially related to traditional agricultural activities, such as grazing and small-scale cultivation. Above all, the reduction of grazing in higher altitude areas has induced diversified natural reforestation phenomena in relation to site-specific conditions. This renaturalization process occurred with a secondary succession in forest habitats or filled holes in pre-existing forests related to livestock staging areas $[17,18]$.

These dynamics are typical of many mountainous areas of the Mediterranean, as well as extra-Mediterranean; in fact, it is possible to find in literature many case studies in Greece, France, Spain and Portugal [19]. In Italy, there are many case studies involving both areas near the Alps and along the Apennines [6,14,20-22].

To understand the effects and therefore carry out specific studies and research, however, it is necessary to be clear about the trends of abandonment and to evaluate the temporal dynamics. Especially when dealing with rural and forest landscapes, by definition, the temporal factor is fundamental. In general, field data are rarely used because they are spatially limited, not applicable to very large scales and have temporal limitations [23]. The approaches used most are those that use geographical information systems (GIS) as an integrated tool for different types of geodata and methodologies [24,25].

Especially when multitemporal land cover geodata are needed, a GIS-based approach is essential [26,27]. This provides for the integration of several types of data, often widely varied and requiring different preprocessing and elaboration techniques. The current trend is to use mainly satellite images, but their exclusive use implies limiting the period of study to about forty years. For this reason, it is also necessary to use other types of remote sensing data (historical aerial photos) and cartographies or historical maps in order to trace the dynamics of transformation over time of the territory from different points of view (anthropic, agricultural and naturalistic).

This is possible using and integrating historical cartographies together with other types of cartography and aerial photos, which allows for recovery of territorial geodata for very long time. The historical cartography can contribute as a primary source to an understanding of not only configuration and conformation of landscape patterns, but also processes and dynamics that influence them. In fact, historical cartography is one of the representational elements through which it is possible to reconstruct not only the persistent and/or permanent signs of past territorial settlements, but also the actions of landscape modeling, and therefore imagine both interventions of protection/conservation of geographical objects with identity value, and reactivation of resources through good planning practices of innovative management of the landscapes concerned $[28,29]$.

Even if complex to manipulate and with some errors, they are indeed the only source to process spatialized land cover and land use data, especially when changes are relevant [30]. To use this data source in a way that minimizes errors, however, geographic tools must be leveraged to both process the data and make it comparable to each other. In fact, some new open-source tools allow for both at great cost and time savings [31]. Thus, implementing a historical GIS that integrates historical and modern thematic cartography is critical to reconstructing the dynamics of the forest landscape.

In this study, the Basilicata region (Southern Italy) was chosen as it represents a real "open-air laboratory" [32]. There are many of the typical landscape types of the Mediterranean area comprising different dynamics of transformation, which have not 
been thoroughly studied [22]. Moreover, even the forest landscape, largely conditioned by human activity and subject to transformations also due to climate change [33,34], has a history and characteristics [35] that require specific and multidisciplinary studies to try to reconstruct the spatial dynamics that have occurred in the last 150 years. In addition, the configuration and conformation of the forests and land cover continuity are part of the landscape visual quality, which is very high in this region [36]. After a long activity of cartographic research and accessing freely available datasets, the forest cover was mapped for a period of almost 160 years (years 1860, 1910, 1936, 1950, 2000, 2006 and 2018) in order to evaluate the spatial variations and the relationships with selected topographic variables (altitude, slope, orientation and geomorphology) to assess where, when and how the forest landscape changed.

All procedures were carried out only in FoSS (free and open-source software) environment within an open-source geographical information system (QGIS 3.16) which, using different plugins and interoperability with other software, allows workflow in a unique software environment. This approach assures the opportunity to integrate different types of geodata from historical cartography, with datasets ranging from classical cartography to remotely sensed data (aerial photos, orthophotos and satellite images), which are used as primary or ancillary data for accuracy verification or subsequent spatial analysis [37].

In addition, for a first spatial survey, forest areas cleared in the past were related in order to evaluate their current evolution in terms of land cover and vegetation. In addition to an approach and a methodology usable in different contexts, the objective of this case study is to create a historical GIS that can support those involved in landscape planning in this study area, a region with internationally recognized historical, cultural and naturalistic value.

\section{Materials and Methods}

\subsection{Study Area}

The study area (Figure 1) corresponds to the Basilicata region (Southern Italy) and covers an area of $1,007,332 \mathrm{~km}^{2}$. It is the penultimate Italian region in terms of population density (about 55 inhabitants $/ \mathrm{km}^{2}$ ) but it represents the first Italian region with the highest ratio of protected area per inhabitant. The Basilicata region presents a territory classified mostly as highlands and hills ( $47 \%$ and $45 \%$ respectively). Only in the east, in the short stretch of coast on the Ionian Sea, is there the largest flat area of the region ( $8 \%)$. From the orographic point of view, south of the volcanic area of Vulture begins the Apennine zone, within which fall some of the highest massifs of the entire southern Apennines, which is divided into five distinct groups. The entire eastern side is occupied by a hilly area which, due to the geolitical constitution of the soils, undergoes continuous changes due to erosive phenomena to gully areas devoid or almost devoid of vegetation. The flat areas, identifiable in Metaponto plain in the southeast, originated by continuous accumulation of eroded material transported downstream by rivers.

From a biogeographical point of view, the entire region falls within the Mediterranean area and there is climatic variability determined by the extreme orographic and morphological variability of the territory. In fact, the western area has oceanic/suboceanic climatic characteristics with precipitation values higher than $1500 \mathrm{~mm}$ of annual rainfall, which decrease almost to $300 \mathrm{~mm}$ toward the internal and eastern areas, with continental characteristics and areas that can be classified as subarid. The current territorial configuration can be traced back to the presence of different paleogeographical domains. The geological and geodynamic evolution, recorded since the Triassic Period and continued in a discontinuous manner until today, has contributed to the strong differentiation of the landscape, making it unique within the entire Apennine chain. This large geomorphological and climatic variety has determined the creation of an important diversification of the ecosystems both in terms of species and habitats; in fact, it is possible to find both coastal and subalpine habitats within a radius of a few kilometers. This high biodiversity and the low anthropic pressure 
(except in a few industrial areas) make the Basilicata region a hotspot for Mediterranean biodiversity [38].

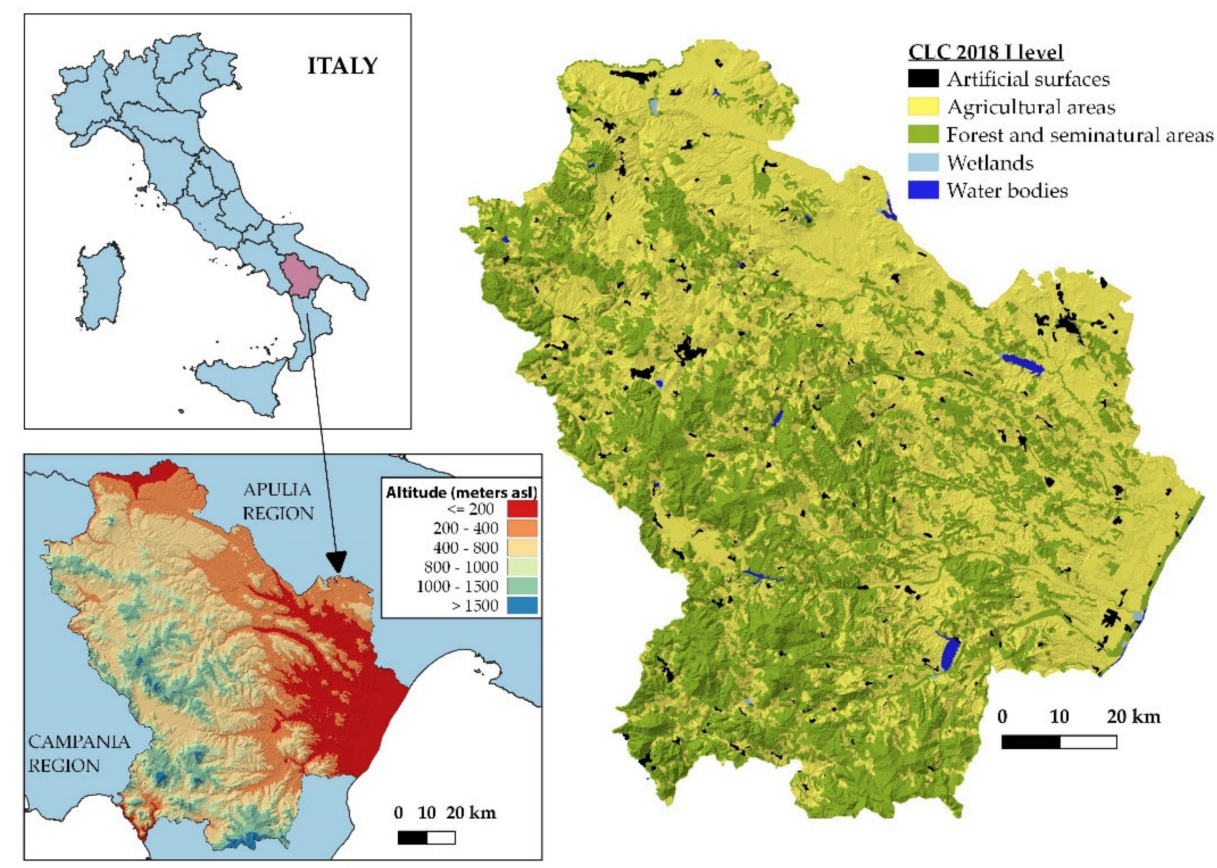

Figure 1. Location of the study area within Italy with maps showing altitude and land cover using CORINE Land Cover I Level 2018. Centroid: $40^{\circ} 29^{\prime} 51.9^{\prime \prime}$ N $16^{\circ} 06^{\prime} 10.6^{\prime \prime}$ E (EPSG:4326).

\subsection{Preliminary Cartographic and Geospatial Operations}

The first part of the work concerned the collection and elaboration of the basic cartography and dataset useful for the realization of the historical GIS of the Basilicata region, which started with the work proposed in other papers [39,40]. Considering the absence of a digital archive concerning historical cartography, a detailed and capillary survey was carried out in the archives and libraries in order to retrieve and evaluate the cartography useful for the purpose of the research. On the other hand, recent datasets were obtained by researching open data freely available online. In consideration of the needs and aims of the work, the maps and datasets briefly described in Table 1 were selected. Primary steps and all the following procedures were implemented with open-source GIS software 3.16 [41] along with some other tools to provide efficient analysis of forest trends. Considering the typological differences of the data, several processing operations were applied in order to digitize the data and make them comparable. From the cartographic and geographical operations, it was possible to implement an historical GIS that covers almost 160 years and refers to the following years: 1860, 1910, 1936, 1950, 2000, 2006 and 2018. Specific frameworks and methodologies permitted comparison of historical and contemporary maps [42]. 
Table 1. Cartographies and datasets used in this study.

\begin{tabular}{|c|c|c|c|c|c|c|}
\hline N. & Title & Year & Source & Typology & Hard Copy/Digital & Brief Description \\
\hline 1 & $\begin{array}{l}\text { Il territorio per immagini: } \\
\text { Atlante della } \\
\text { Basilicata-Cartografia a } \\
\text { stampa moderna-Istituto } \\
\text { grafico italiano, } 1987\end{array}$ & 1860,1910 & $\begin{array}{l}\text { National Library, Potenza, } \\
\text { Italy }\end{array}$ & $\begin{array}{l}\text { Topographic map } \\
\text { with themes. } \\
\text { Scale } 1: 250,000\end{array}$ & Hard copy & $\begin{array}{c}\text { Representation of areas } \\
\text { with existing forests in } \\
\text { Basilicata region in } 1860 \\
\text { and 1910, and deforested } \\
\text { areas }\end{array}$ \\
\hline 2 & $\begin{array}{c}\text { Die Wälder der Basilicata } \\
\text { und die Entwaldung im } \\
\text { 19. Jahrhundert. } \\
\text { Vorgänge, Ursachen und } \\
\text { Folgen. Heidelberger } \\
\text { Geographische Arbeiten } \\
\text { 8, Tichy F. [43] }\end{array}$ & $1860,1936,1950$ & $\begin{array}{l}\text { University of Basilicata, } \\
\text { SAFE-School of } \\
\text { Agricultural, Forest, Food } \\
\text { and Environmental Science }\end{array}$ & $\begin{array}{l}\text { Thematic map. } \\
\text { Scale } 1: 100,000\end{array}$ & Hard copy & $\begin{array}{l}\text { Representation of the } \\
\text { forest areas, deforested } \\
\text { for different periods for } \\
\text { the whole Basilicata } \\
\text { region }\end{array}$ \\
\hline 3 & $\begin{array}{l}\text { Carta forestale del Regno } \\
\text { d'Italia, 1936-Milizia } \\
\text { Forestale }\end{array}$ & 1936 & $\begin{array}{c}\text { http: / / carta1936.dicam. } \\
\text { unitn.it / (accessed on } \\
\text { 1 July 2021) }\end{array}$ & $\begin{array}{l}\text { Topographic map } \\
\text { with themes. } \\
\text { Scale 1:50,000 }\end{array}$ & Digital vector file & $\begin{array}{l}\text { Forest map with } \\
\text { indications on species and } \\
\text { form of management for } \\
\text { the whole of Italy }\end{array}$ \\
\hline 4 & $\begin{array}{l}\text { CORINE Land Cover } \\
\text { (CLC) inventory }\end{array}$ & $2000,2006,2018$ & $\begin{array}{l}\text { https:/ /land.copernicus. } \\
\text { eu/pan-european/corine- } \\
\text { land-cover (accessed on } \\
\text { 1 July 2021) (European } \\
\text { Union, 2018) }\end{array}$ & $\begin{array}{l}\text { Thematic digital } \\
\text { map }\end{array}$ & Digital vector file & $\begin{array}{l}\text { Land cover map } \\
\text { according to CORINE } \\
\text { land cover standards }\end{array}$ \\
\hline
\end{tabular}

\subsection{Implementation of Historical GIS}

The first phase involved the creation of base layers useful to build the historical GIS. The operations involved both the digitization of the historical cartographies (Figure 2), and the selection of the online thematic maps, and the extrapolation of the attached geoinformation [44]. The digitization of the historical cartography (N. 1-2 in Table 1) was performed in a similar manner as they both possess similar characteristics. After the scanning phase, the maps in TIF format were georeferenced by converting the geographic grid shown on the maps to a planimetric coordinate system (EPSG: 32633 UTM/WGS84 $33 \mathrm{~N}$ ). The root mean square (RMS) errors of georeferencing are negligible given the accuracy of the original coordinate systems. In fact, they were approximately 20 meters. As for the historical cartography, N. 3, it was possible to use the already digitized version in vector format and freely available online with Creative Commons Attribution-Version 3.0 @ CFS, CREA, DICAM UNITN [45].
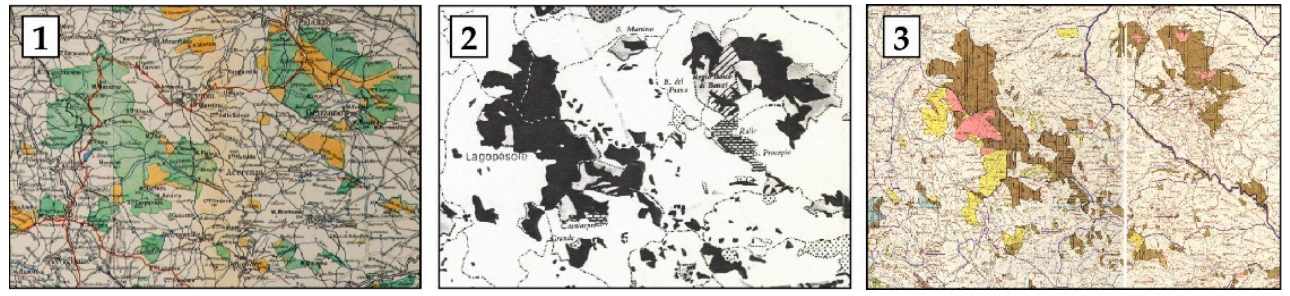

Figure 2. Extracts from historical cartographies of the same portion of the study area. Numbers refer to Table 1 in which the characteristics of maps are reported.

The processing of these three types of historical cartography allowed reconstruction of the forest dynamics for the years 1860, 1910, 1936 and 1950. For the elaboration related to the years 2000, 2006 and 2018, reference was made to the datasets freely available online and provided by the Copernicus Land Monitoring Service (European Union, 2021). The main features are reported in Table 2 . Being in vector format, they were only cropped with respect to the boundaries of the study area and reprojected in the same reference system.

\subsection{Forest Dynamics Geodatabase}

Once the cartographic and thematic layers were implemented within the historical GIS, the geodatabase of the forest areas of the years of analysis was created. Since they were already in a classified vector format for the years 1936, 2000, 2006 and 2018, only aggregations and exclusions were made in order to extract only the land cover classes identifiable as "forest area". For the years 1860, 1910 and 1950, instead, a digitization was carried out. To do this, polygonization and classification techniques were used, 
partly manually and partly automatically. The latter technique was used for those themes that presented clear chromatic differentiations, which made it possible to exploit the interoperability between QGIS and the graphics software GIMP [47]. In fact, since GIMP is able to store geographic projection information and able to communicate with the QGIS 3.16 plugin, it was possible to greatly speed the digitalization of some forest features.

Table 2. Main features of the datasets used for the years 2000, 2006 and 2018, as reported in the metadata and technical documents [46].

\begin{tabular}{|c|c|c|c|}
\hline Characteristics & CLC2000 & CLC2006 & CLC2018 \\
\hline Satellite & $\begin{array}{l}\text { Landsat-7 ETM } \\
\text { single date }\end{array}$ & $\begin{array}{l}\text { SPOT- } 4 / 5 \text { and } \\
\text { IRS P6 LISS III }\end{array}$ & $\begin{array}{l}\text { Sentinel-2 and } \\
\text { Landsat- } 8 \text { for corrections }\end{array}$ \\
\hline Temporal reference & $2000 \pm 1$ year & $2006 \pm 1$ year & 2017-2018 \\
\hline $\begin{array}{l}\text { Satellite image } \\
\text { Spatial accuracy }\end{array}$ & $\leq 25 \mathrm{~m}$ & $\leq 25 \mathrm{~m}$ & $\leq 10 \mathrm{~m}$ (Sentinel-2) \\
\hline $\begin{array}{l}\text { Minimum mapping } \\
\text { unit/width }\end{array}$ & $25 \mathrm{ha} / 100 \mathrm{~m}$ & $25 \mathrm{ha} / 100 \mathrm{~m}$ & $25 \mathrm{ha} / 100 \mathrm{~m}$ \\
\hline CLC Spatial accuracy & less than $100 \mathrm{~m}$ & less than $100 \mathrm{~m}$ & less than $100 \mathrm{~m}$ \\
\hline
\end{tabular}

In addition, using the information contained within the historical cartographies N. 1-3, it was also possible to map the areas in which the forests have been cleared, so as to make subsequent considerations and evaluations on the evolution of these areas from a vegetation point of view. This was done through a spatial overlay compared to the Nature Map of the Basilicata region [48], which provides the vegetation classification of the territory. This was then used to evaluate how the areas that were cleared before 1950 have been transformed.

\subsection{Stastistic Analysis on Forest Areas}

The mapping of forest areas allowed us to localize the evolution of forests during the 158 years used in the analysis. To better define "where", forests were related to topographic and geomorphologic parameters selected for evaluating former and present portions of the territory covered by forests and how these parameters changed through time [49]. The quantitative parameters, expressed through a raster map (Figure 3), are:

- Altitude (meters a.s.l.) obtained from the digital terrain model (DEM) provided by the National Geoportal [50], with a horizontal pixel resolution of $20 \mathrm{~m}$;

- $\quad$ Slope (degrees) calculated from the DEM through QGIS;

- Orientation, calculated in degrees through QGIS and then reclassified into Flat, N, S, E, W, SE, SW, NE, NW);

- Geomorphological classes, calculated through the GRASS GIS plugin r.geomorphon, allows using the DEM and setting some specific variables within the plugin to classify the territory into classes defined as flat, summit, ridge, shoulder, spur, slope, hollow, footslope, valley and depression [51,52]. Furthermore, in this case there is a category "Flat", but it is calculated differently than that of the orientation because it is a different aspect.

The descriptive statistics and box plot of slope, elevation, orientation and geomorphology versus forest areas for each year were then used to assess the distinction of native classes with respect to topographic parameters. The same operation was done for forest areas lost prior to 1950 . 


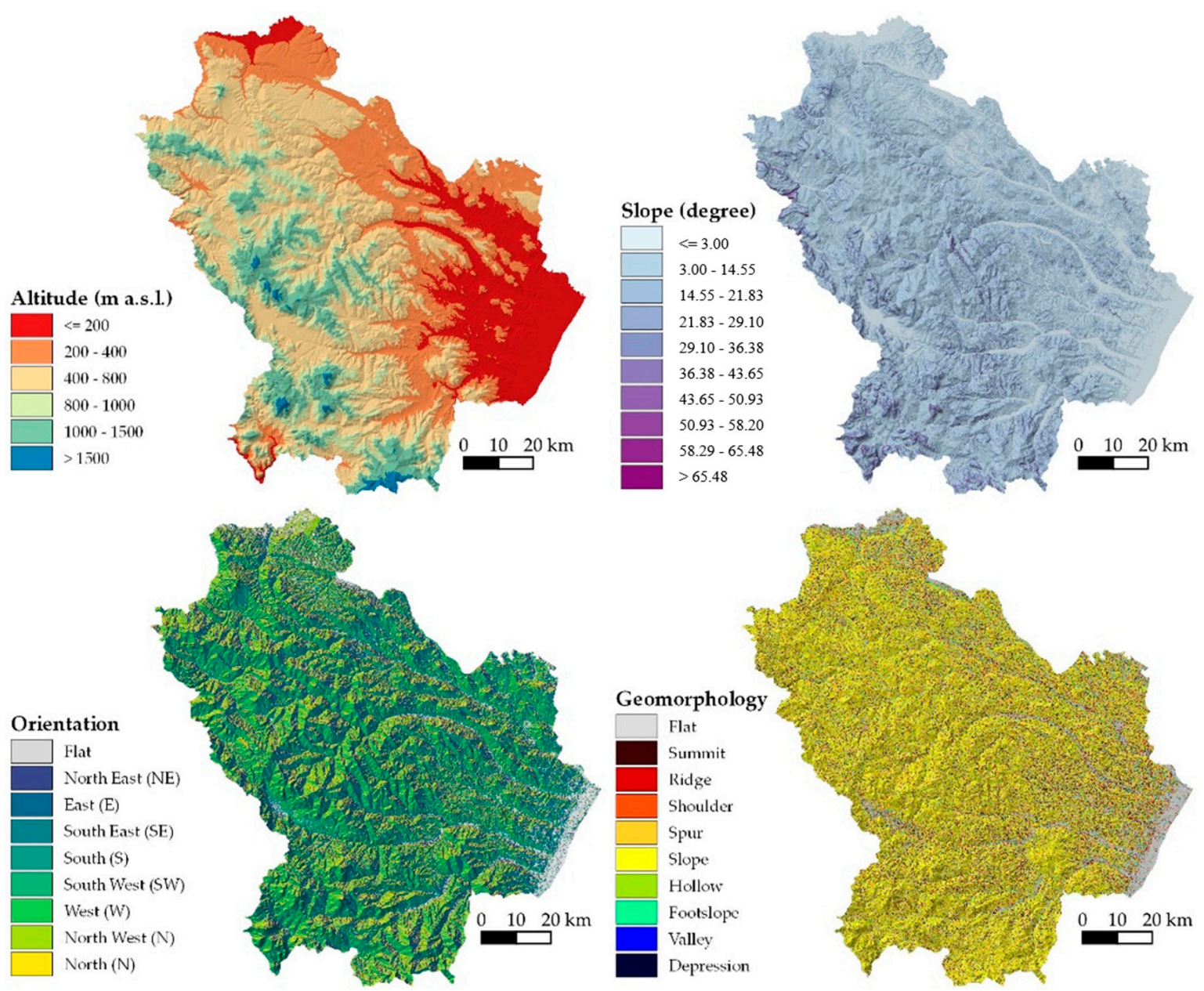

Figure 3. Processed quantitative topographic parameters used as the basis for the forest cover statistical survey.

\section{Results}

\subsection{Forest Cover Dynamics within 158 Years of Analysis}

The implementation of the historical GIS through the use of different cartographies allowed harmonization of the data, making them comparable with each other and enabling mapping of forest cover from 1860 to 2018, which could be done with accuracy and geographic criteria. Therefore, forest maps for the years 1860, 1910, 1936, 1950, 2000, 2006 and 2018 were realized (Figure 4).

This allowed us to spatialize the data and then use it as a starting point for subsequent analyses. The first evaluation concerned the transformations in terms of surface area. In fact, an analysis of Table 3 and Figure 5 shows a fairly clear trend in forest cover in the Basilicata region. In the first and the last year of the study, the forest area and the corresponding forest cover index (percentage ratio between forests and area of the Basilicata region) were similar (over 27\%). Between 1860 and 1950 there was a large decrease with a minimum value recorded in 1936 (almost 15\% relative to the entire territory). Starting from 1950, however, the trend reversed and continued through the years 2000 and 2018.

In Table 4, these variations are expressed as net change (ha and \%) and annual changes $(\%)$, determined by analyzing pairs of successive years so as to highlight in even greater detail the rates of increase and decrease in terms of both intensity and speed. It is necessary to take into account the fact that there is not the same number of years between one period and another. For this reason, the annual change (\%) should be read and considered with this issue in mind. The data that are most obvious show that between 1936 and 1950 there was the greatest increase (about $33 \%$ ), with an annual change of $+2.42 \%$, and that in the last period the increase rate seems to have slowed $(+0.36 \%$ each year). In contrast, in terms of 
reductions, the most intense and rapid decrease occurred between 1910 and $1936(-0.87 \%$ each year).

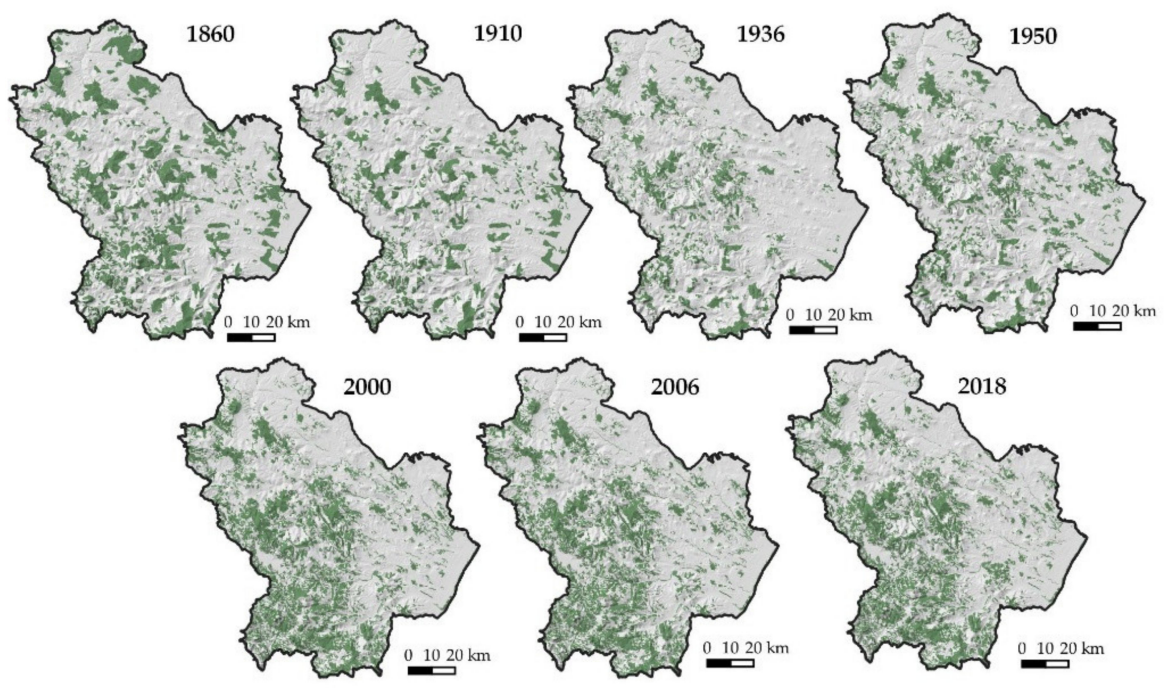

Figure 4. Forest cover map for years of analysis.

Table 3. Area in hectares of forests and percentage of total area of Basilicata region (forest cover index).

\begin{tabular}{ccc}
\hline Year & Hectares (ha) & Forest Cover Index $\mathbf{1} \%$ \\
\hline 1860 & $277,071.1$ & 27.51 \\
1910 & $194,888.09$ & 19.35 \\
1936 & $150,958.80$ & 14.99 \\
1950 & $201,996.09$ & 20.05 \\
2000 & $252,910.76$ & 25.11 \\
2006 & $268,125.62$ & 26.62 \\
2018 & $279,586.31$ & 27.76 \\
\hline
\end{tabular}

${ }^{1}$ Percentage with respect to the entire surface area of the Basilicata region $(1,007,332 \mathrm{ha})$.

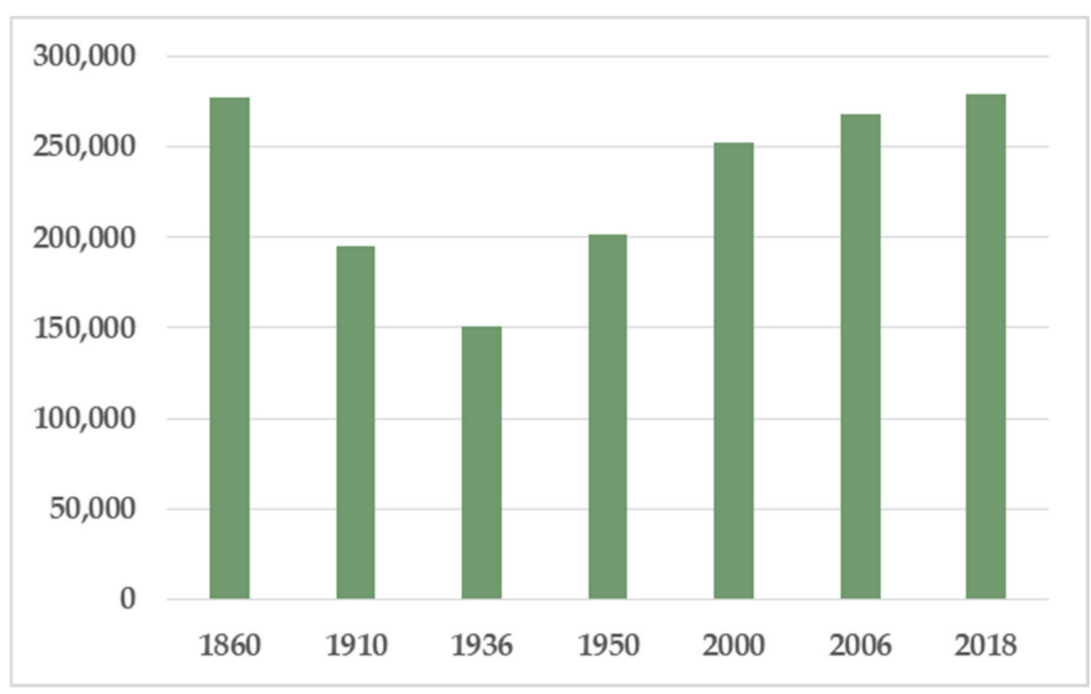

Figure 5. Bar graph of forest area (in hectares) in analysis years. 
Table 4. Calculation of net change (ha), net percent of change and annual change for each successive pair of years.

\begin{tabular}{cccc}
\hline Period & Net Change (ha) & \% of Change $^{\mathbf{1}}$ & Annual Change (\%) $^{\mathbf{2}}$ \\
\hline $1860-1910$ & $-82,183.00$ & -29.66 & -0.59 \\
$1910-1936$ & $-43,929.30$ & -22.54 & -0.87 \\
$1936-1950$ & $51,037.30$ & 33.81 & 2.42 \\
$1950-2000$ & $50,914.67$ & 25.21 & 0.50 \\
$2000-2006$ & $15,214.86$ & 6.02 & 1.00 \\
$2006-2018$ & $11,460.69$ & 4.27 & 0.36 \\
\hline
\end{tabular}

${ }^{1}$ Net change divided by the hectares of the year before. ${ }^{2} \%$ of change divided by the number the years in the period.

The geostatistical analysis allowed us to carry out a preliminary analysis of the relationships between changes in forest cover and some commonly used topographic parameters that historically have most influenced the use of forests, i.e. altitudes, slope, exposure and land morphology. Basically, all topographic parameters were obtained from the same digital terrain model, but given their characteristics, each one allows us to evaluate and analyze a particular feature of the territory examined.

Concerning exposure and slope (Tables 5 and 6 ) and considering the characteristics of the data, some descriptive statistics (mean value, standard deviation, minimum and maximum) were calculated and shown in box plots.

Table 5. Descriptive statistics related to altitude (meters a.s.l.) for each year of analysis.

\begin{tabular}{ccccc}
\hline Year & Mean Altitude & St. Dev. & Min. & Max. \\
\hline 1860 & 677.27 & 375.83 & 0 & 2175 \\
1910 & 695.86 & 390.81 & 0 & 2125 \\
1936 & 810.23 & 343.95 & 0 & 2088 \\
1950 & 713.30 & 381.11 & 0 & 2238 \\
2000 & 757.77 & 338.72 & 0 & 2125 \\
2006 & 756.37 & 339.61 & 0 & 2125 \\
2018 & 763.54 & 337.39 & 0 & 2125 \\
\hline
\end{tabular}

Table 6. Descriptive statistics related to slope (degrees) for each year of analysis.

\begin{tabular}{ccccc}
\hline Year & Mean Slope & St. Dev. & Min. & Max. \\
\hline 1860 & 13.83 & 10.00 & 0.00 & 76.79 \\
1910 & 14.60 & 10.26 & 0.00 & 76.79 \\
1936 & 15.95 & 10.00 & 0.00 & 76.00 \\
1950 & 15.16 & 9.93 & 0.00 & 74.91 \\
2000 & 16.66 & 10.02 & 0.00 & 76.79 \\
2006 & 16.64 & 10.06 & 0.00 & 76.79 \\
2018 & 16.79 & 10.04 & 0.00 & 76.79 \\
\hline
\end{tabular}

Analyzing first the altitude parameter, we notice that in 1936 the forests affect a territory that has the highest average altitude ( $810 \mathrm{~m}$ a.s.l.) (Table 5), as it is also evident from the box plot in which (Figure 6, top) the distribution is noticeably reduced compared to the other years, and especially shifted more towards higher altitudes. In contrast, if we analyze the last 3 years of analysis (2000, 2006 and 2018) it emerges that the distribution and the statistical values are more or less identical. Instead, the periods in which there were more intense changes $(1860,1910$ and 1950) are also those in which forests occupied different shares of the territory. A similar trend was recorded for slope in that for the last 3 years of analysis (Table 6), the classes affected are nearly identical. In addition, for all years, a high deviation between mean values is not noted. Only in 1860, an average value of slope is noted that is almost 2 degrees lower than that recorded in 2018. Regarding the 
general maximum and minimum recorded values for both elevation and slope, there is not much difference between one year and another.
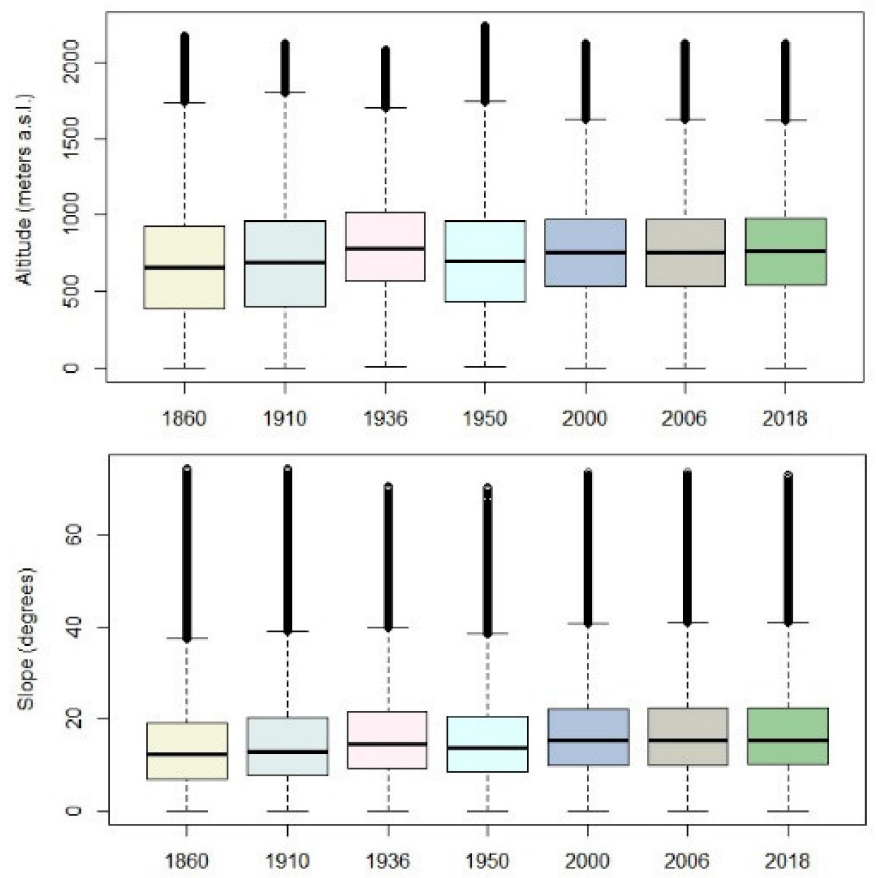

Figure 6. Box plots of topographical parameters (altitude and slope) for each year of analysis. Circles specify outliers; the horizontal lines within the box specify the median value of each parameter. The bottom of box is at the first quartile ( $25 \%$ of the distribution), and the top is at the value of the third quartile $(75 \%$ of the distribution), while the whiskers indicate variability outside the upper and lower quartiles.

Exposure and morphology, organized by classes, were statistically analyzed by making histograms of the cumulative percentage frequencies for each class within each year (Figures 7 and 8).

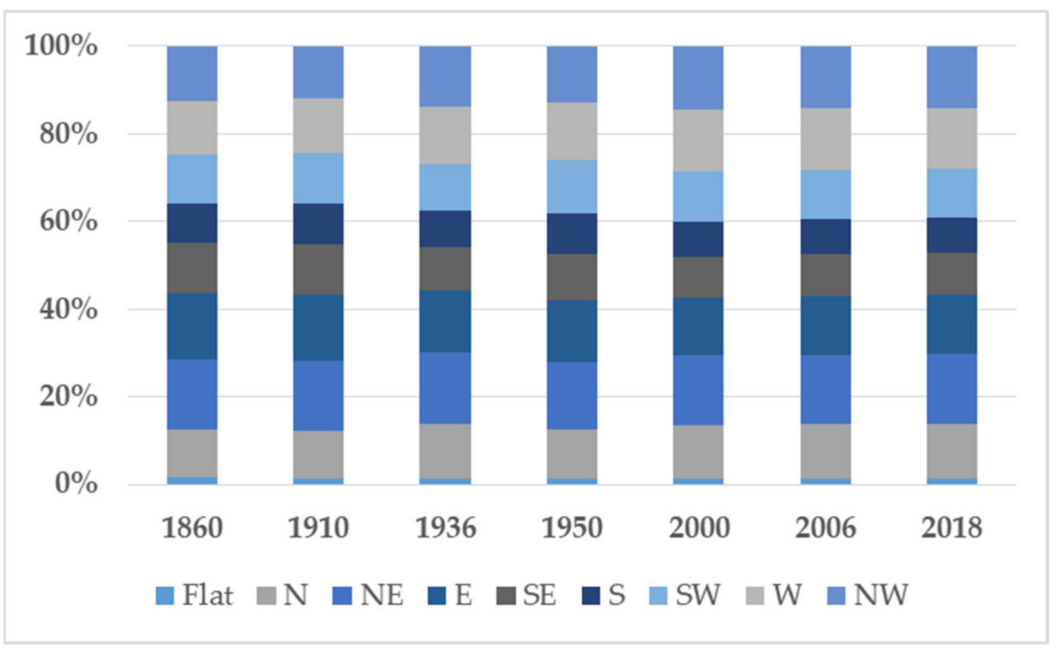

Figure 7. Frequency distribution histograms (\%) for each orientation class. 


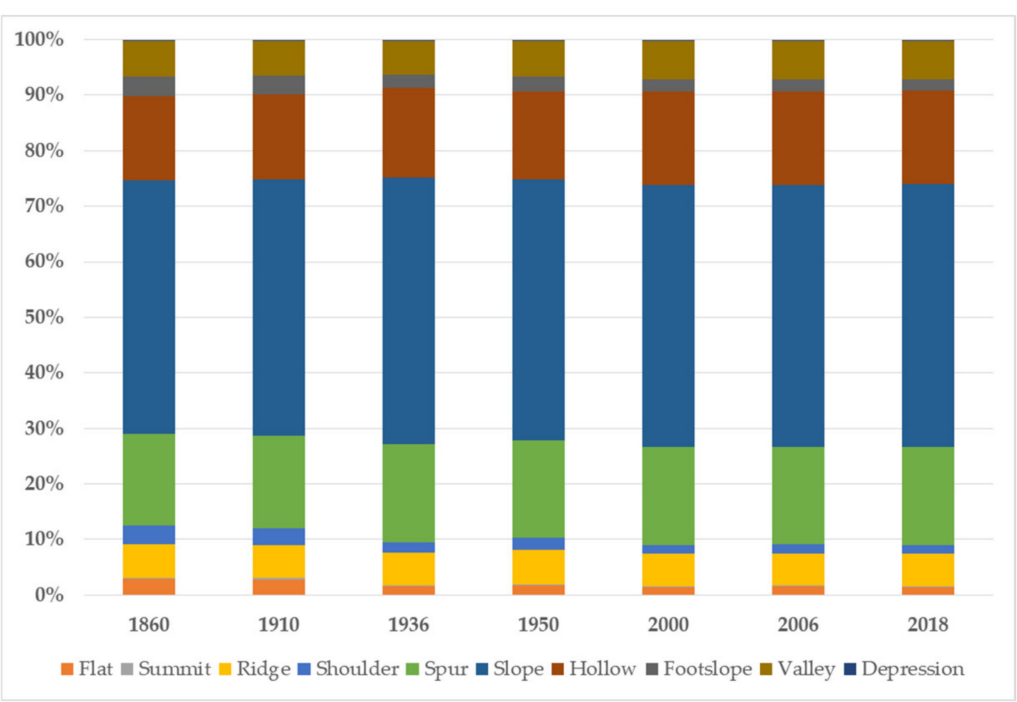

Figure 8. Frequency distribution histograms (\%) for each geomorphology class.

Concerning exposure, there is no predominant orientation for each year analyzed. This is also due to the fact that the forest dataset is generic and are not categorized by forest typology. The only useful observation is that the forests, for all years of analysis, are more distributed in the north (N, NE and NW) than in the south (S, SE and SW). For the geomorphological aspects, a more or less homogeneous distribution of the forests in each year of analysis can be observed. However, between 1860 and 2018 we notice two classes, flat and footslope, that possess a higher frequency and are slightly less than twice in 1836 than in 2018.

\subsection{Analysis of Forests Present before 1950}

The use of GIS for diachronic analysis and transformation dynamics has the advantage of modeling capability on the basis of scientific and planning needs through its potential to perform diversified spatial analysis.

In this study, in consideration of the information present on the maps, we chose to highlight an important aspect from an ecological and landscape point of view, that is, which areas have undergone deforestation before 1950 (Figure 9, left) and how have they changed. Furthermore, by aggregating the different areas it was possible to relate them through a spatial overlap with the geodata present on the 2013 Nature Map [48]. This map, even if it predates the CORINE land cover 2018 (Table 1), presents vegetation and ecological information (classification according to CORINE biotopes) of considerable detail and accuracy. For this study, some classes were merged to improve the interpretation of dynamics.

Figure 9 shows how forested areas that were cleared prior to 1950 (Figure 9, right) have changed (in terms of land cover) (Figure 9, left). The map shows that the areas are very fragmented except for a few very large areas. Once again, the mapping allowed areal measurement of forests to be computed. Over 38\% (Table 7) of the forest areas cleared prior to 1950 resulted in arable lands in 2013, and only 33\% have "turned back" to forest. If tree crops are also taken into account, agricultural areas reach almost $44 \%$. A small part, however, has undergone soil consumption due to artificial processes $(0.59 \%)$ and a part has suffered erosion in badlands (0.99\%). Figure 10, through a Sankey diagram [53], graphs the dynamics of transformation that damaged deforested areas, and allows us to evaluate visually and immediately the transformations. 

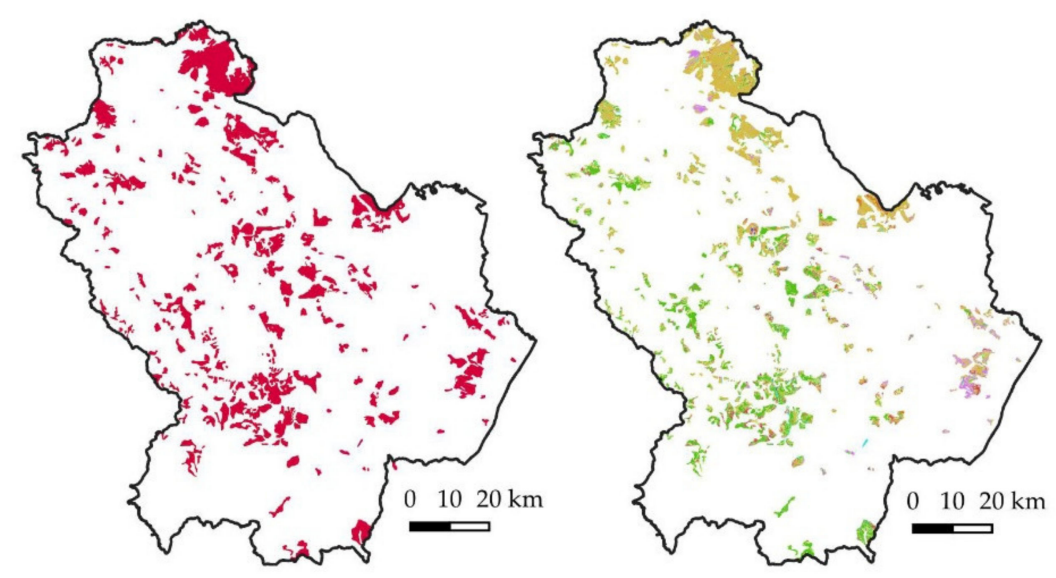

Forest areas cleared before 1950
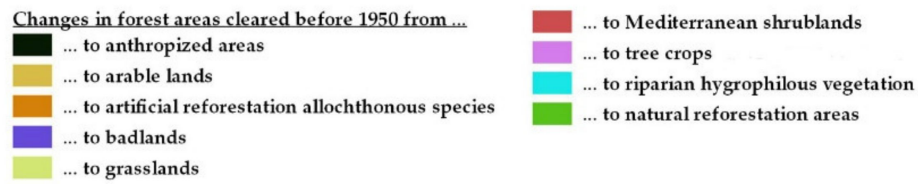

Figure 9. Forest areas cleared prior to 1950 (left) and mapping of how forest areas cleared prior to 1950 were transformed (right).

Table 7. How forest areas cleared prior to 1950 have changed; for each category into which they have changed, the acres and percentage to total are shown.

\begin{tabular}{ccc}
\hline Category of Change & ha & \% \\
\hline ... to anthropized areas (urban centers, roads, industries, quarries, etc.) & 654.94 & 0.59 \\
$\ldots$. to badlands & 1105.34 & 0.99 \\
$\ldots$ to artificial reforestation allochthonous species & 1739.68 & 1.56 \\
$\ldots$ to riparian hygrophilous vegetation & 1840.44 & 1.65 \\
$\ldots$ to tree crops: olive groves, vineyards, orchards, etc. & 6560.56 & 5.87 \\
$\ldots$ to Mediterranean shrublands & 8711.91 & 7.80 \\
$\ldots$... to grasslands & 11244.68 & 10.06 \\
$\ldots$ to natural reforestation areas & 36848.91 & 32.98 \\
$\ldots$ to arable lands & 43038.52 & 38.51 \\
\hline Total Forest Area Cleared Before 1950 & 111744.98 & 100.00 \\
\hline
\end{tabular}

For an initial investigation, the deforested area in 1950 was related to the topographic parameters previously indicated. If we analyse the box plots of Figure 11 concerning altitude and slope, we notice that the range of values recorded are quite limited to some bands of the territory where the median values are approximately $500 \mathrm{~m}$ a.s.l. and with a slope of roughly 10 degrees. These values are lower than those recorded on average with the analysis of forest cover. Frequency histograms were also elaborated for orientation and geomorphology (Figure 12). For orientation, there are basically no classes that are more represented than others and they are in line with those that characterize forest cover (Figure 7). There are also no variations in geomorphology with respect to the forest areas. However, here too we must point out an important fact from an ecological and vegetational point of view, i.e. that part of the deforestation took place in flat areas. 


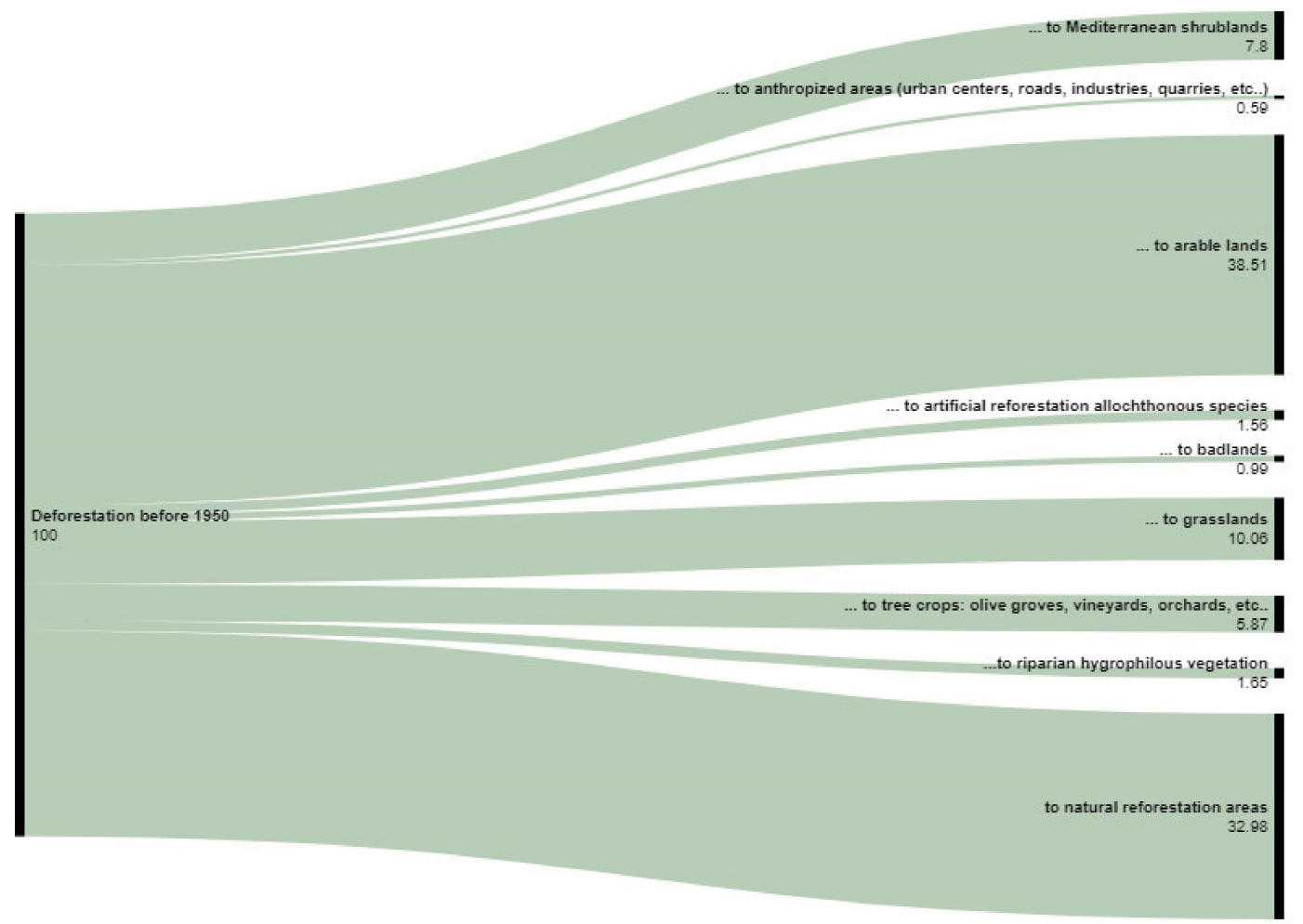

Figure 10. Sankey diagram for the dynamics of transformation of the forest area cleared before 1950 (deforestation area). The values are reported in percentage as in Table 7.
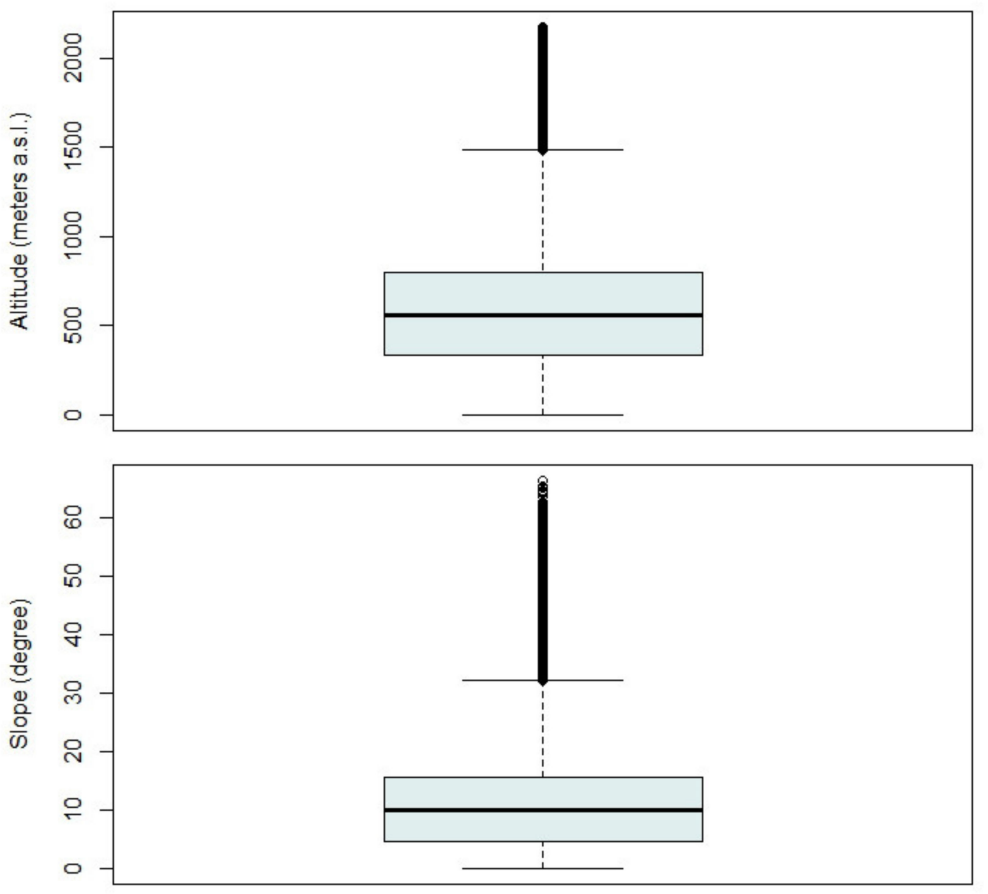

Figure 11. Box plots of topographical parameters (altitude and slope) for forest area cleared before 1950. Circles specify outliers; the horizontal lines within the box specify the median value of each parameter. The bottom of the box is at the first quartile ( $25 \%$ of the distribution), and the top is at the value of the third quartile (75\% of the distribution), while the whiskers indicate variability outside the upper and lower quartiles. 

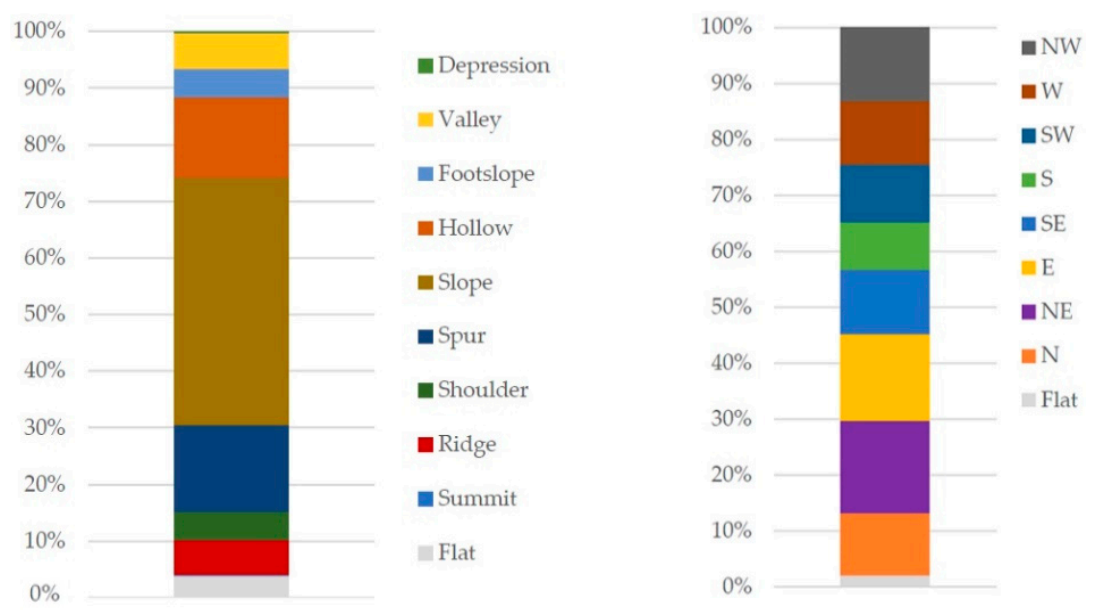

Figure 12. Frequency distribution histograms (\%) for each geomorphology class (left) and for each orientation class (right).

\section{Discussion}

\subsection{The Transformation Dynamics of Mediterranean Forest Landscapes}

Forest expansion is a process that is taking place almost everywhere in the hilly and mountainous areas of the Mediterranean and globally in mountainous areas. In fact, there are many studies both for different European countries [54] and non-European countries $[55,56]$. In the Mediterranean areas, however, this process is occurring faster, because the landscape and the territory have been strongly shaped by the traditional agro-silvopastoral activities that have almost completely disappeared for different socioeconomic causes and with different levels of rewilding [57].

This transformation of the territory in the Mediterranean basin and especially in Italy can be divided into two phases. The first involved the strong process of deforestation following the economic development of the early 20th century and post-World War II for the recovery of timber and the subsequent cultivation of land until the 1950s and 1960s. The second, however, concerns the changes in European agricultural policies and the socioeconomic crisis of recent decades that is leading to the abandonment of marginal inland territories and therefore the expansion of forests. With differences in terms of speed and time period from region-to-region [14], it can be noted that in the last century, Mediterranean forests, after the reduction at the beginning of the century, are steadily increasing, especially in mountainous and hilly areas. Parallel to the socioeconomic issues, transformations in the hilly and Mediterranean inland areas have occurred at different rates in relation to the morphology and characteristics of the territory $[49,58]$.

How much forests are increasing and where they are expanding, however, are the most prominent questions in scientific research. Above all, knowing "how much" is important in the spotlight of the scientific community, since the different forest statistics are often greatly varied due to the different classification of forests, the spatial resolution of the surveys and the availability of data [59-61]. Knowing "where", in contrast, can be increasingly refined through new modern satellite and geospatial technologies.

When we consider landscape and territorial analyses, however, it is also important to include the parameter of time in quantitative and spatial investigations. Especially concerning forest landscapes, the temporal issue is of fundamental importance for historical, cultural and ecological reasons.

\subsection{Historical GIS to Understand How Much and Where Forests Have Increased or Decreased in Basilicata Region}

In addition to understanding "how much" the forest area has changed over the years, the implementation of a historical GIS allows for understanding "where" the changes have occurred, both in geographical terms (useful for spatial statistics and for administrative 
areas) and in territorial terms, i.e., which parts of the territory have maintained or lost forest cover and how it relates to quantitative characteristics (physical parameters).

To create a historical GIS, however, in addition to a thorough bibliographic work, it is necessary to use techniques that allow for minimizing cartographic errors inherent in the historical cartography used [62]. New open-source applications and the interoperability of QGIS with other tools provide methodologies of semiautomatic and manual georeferencing and digitization that speed the work without losing accuracy. As demonstrated in this work, above all, the use of QGIS together with graphics software can be very useful in classifying historical thematic cartography. Synthesizing the results that emerged in this case study of the Basilicata region, the dynamics that have affected the forest landscape are almost the same as those that have occurred in other Italian areas and the Mediterranean generally, as previously cited.

What emerged from this study, which covers a 156 year span, is that the forest area is returning, in terms of surface area, to the values recorded in the first half of the 1800s. These values have been increasing progressively since 1950, resulting from artificial reforestation that began during the period and to renaturalization processes by secondary succession due to the abandonment of agricultural activities (Figure 13) $[5,63]$.
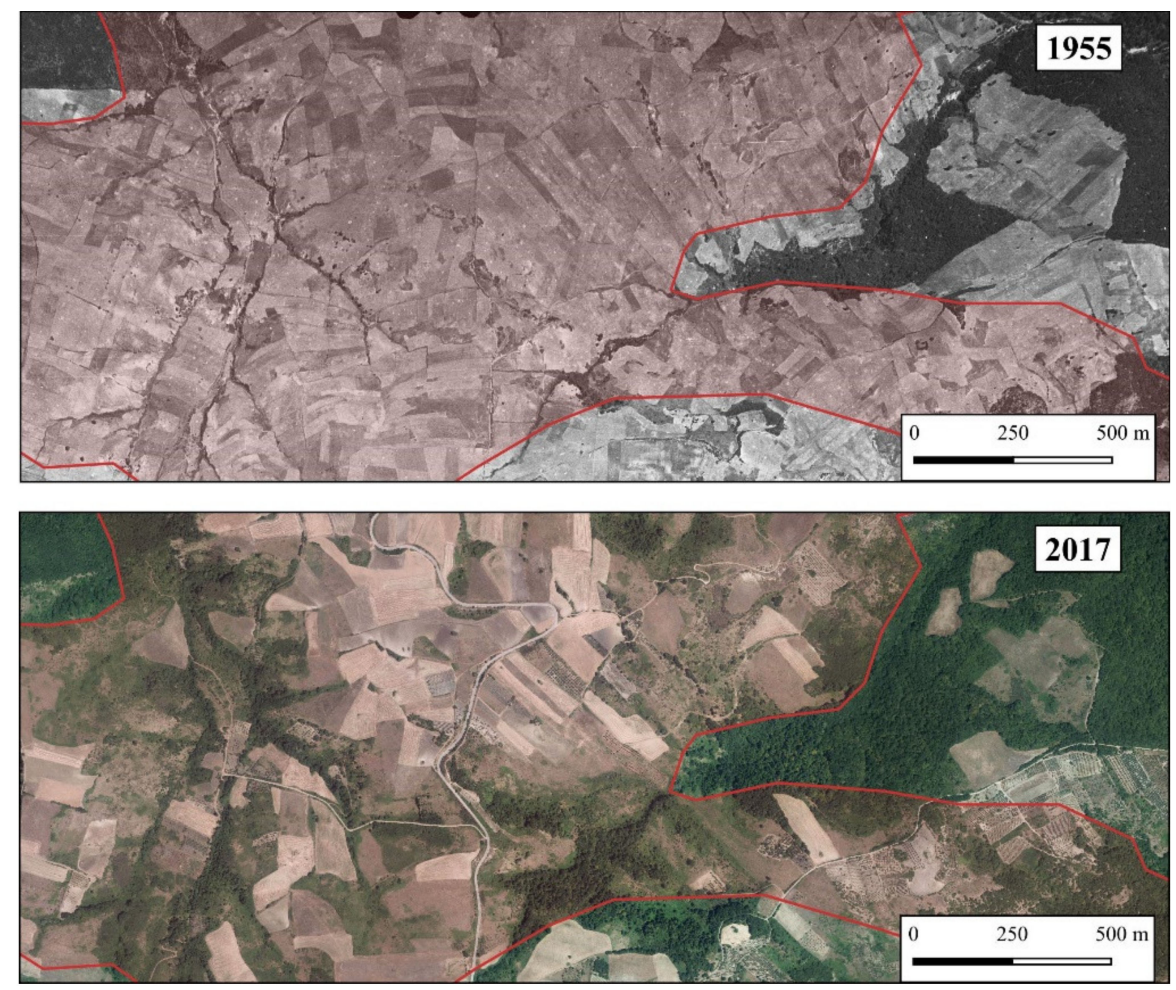

Figure 13. Comparison and verification of reforestation using aerial photos (1955) and digital orthophotos (2017). Red shows forest areas that were cleared in 1950. It can be seen that in 2017 (bottom) the areas have increased and forest recovery is occurring in some of the areas that were forested before 1950 .

Although the areas are the same, the geography of forest landscapes has changed. This can be demonstrated by implementing a historical GIS that takes into account different geodata types. In fact, only $33 \%$ of the forest areas cleared before 1950 has returned to forest (Figure 13). In addition to the statistical data, the historical GIS allows for spatialization of these data in a way that can be used by forest ecologists to evaluate the characteristics of these new forests [64]. Therefore, the position of the forests is partly different from that of 1860. In addition to the geographical location, however, the setting in the territory has also changed in the sense that the forests present in 2018 are positioned (on average) at higher elevations and greater slopes than in 1860. In addition, the forest areas present in flat areas, 
an issue historically very important from an ecological point of view in the Mediterranean area, have been greatly reduced $[65,66]$. This issue also emerged from the geostatistical analysis of forest areas cleared before 1950, which are found to lie between low and reduced values of elevation and slope. In contrast, for the issue related to orientation, there does not appear to be much variation in this very large-scale study.

Obviously, the implementation of this methodology in which the core is represented by the historical GIS, is only the starting point. The characteristics of GIS tools will allow for more complex analyses, adding and calibrating all the subsequent analyses in relation to the objectives. In fact, it is possible to compare historical spatial data with historical statistical data to evaluate differences. When discussing historical cartography, one must take into account that there are cartographic and topographic survey errors that can result in variations in spatial accuracy. Applying the methodologies in this and other work [27,38], however, it was possible to greatly reduce RMS errors. In addition, it is important to consider the fact that historical cartographies represent the only tool to spatially reconstruct land cover before the implementation of new surveying technologies. Thus, it is necessary to use only high quality maps that make it possible to minimize errors and correct inconsistencies [31,59].

Moreover, the characteristics of some historical datasets [40] make it possible to compose future comparisons in terms of forest management forms and specifics, leading to greater detail and understanding of the different aspects of forest landscape transformation in Basilicata region and other areas with a similar or comparable dataset. Finally, the possibility of integrating different remote sensing image processing methodologies (from aerial photos to satellite images) makes it possible for more accurate detection of forest surfaces in recent years (in this case, 2000, 2006 and 2018) and therefore a better understanding of forestry issues $[67,68]$.

The research is based on a study area (Basilicata region) that presents some peculiar characteristics that result from strong, long-term relationships between rural activities and natural habitats [69]. These can also be found in other similar mountain and marginal Mediterranean landscapes [70] and in other important European mountain forest areas [71,72]. Therefore, in areas characterised by a similar forest landscape, both in terms of ecological and morphological structure, this approach can potentially be applicable in other study areas. Furthermore, given the characteristics of the geodata and the fact that the tools are fully open source, the techniques can be replicated and even partly improved in relation to specific needs.

In addition, this and other similar works are at a regional scale [73,74]; however, it is necessary to address issues at a local scale and with greater detail, which would highlight specific phenomena that otherwise would not emerge [37]. In fact, it is important to work at a local scale to increase the knowledge of all Mediterranean environments, thereby providing more data and results for areas with few scientific studies. In addition to the local scale used in this type of analysis, it may be useful to consider homogeneous areas from a socioeconomic and morphological point of view, such as individual landscape units.

\section{Conclusions}

Resilience of agroforestry systems and improvement of ecological networks are environmental objectives strictly connected to how forest landscapes are designed, planned and managed. The forest landscape pattern in the future depends on how such natural and human processes interact over time. Landscapes by definition represent a changing element of the territory. In some cases, however, their historical, cultural and ecological importance requires a specific and detailed approach to avoid the loss or excessive transformation of these landscapes. These transformations are occurring very rapidly in the inland and mountainous areas of the Mediterranean. The abandonment of traditional agriculture is redesigning the patterns and structure of forest landscapes, which are losing their distinguishing peculiarities and cultural characteristics. For this reason, it is necessary to address the issues in multidisciplinary and multitemporal ways. To do this, GIS (espe- 
cially open source) are essential because they can handle many types of data that allow retrieval of historical geographic data that, although with errors, is the only way to have a spatial reference of the historical structure of the territory. Obviously, it is necessary to approach the problems in a standardized way, but also contextualized based on the local situation since historical and socioeconomic dynamics and morphological characteristics can be different, even a few kilometers apart. Therefore, examining a case study can be useful to address some specific aspects of the phenomenon and to increase the already vast but not exhaustive knowledge on the topic of land transformations, land use changes and forest expansion. In particular, the Basilicata region hosts many different territorial contexts, each of which presents a situation similar to other Mediterranean areas. Therefore, it can represent an open-air laboratory for studying the dynamics and evolution of forest landscape changes. In addition, the historical GIS implementation can also be a useful tool for those involved in landscape and forest ecology because it can become the basis of a decision support system, or can provide a method to discriminate areas on which to make more in-depth studies in a context increasingly interested in the relationships between biodiversity and agroforestry landscape transformations.

Author Contributions: The design and conduct of this research is equally shared between the authors. The three authors collaborated to produce this paper. G.C. proposed and developed the research design, methodology, manuscript writing, and data analysis, D.S. and P.P. supervised the work, provided additional comments on the results and interpretation, reviewed and approved the final version. All authors have read and agreed to the published version of the manuscript.

Funding: This research received no external funding.

Institutional Review Board Statement: Not applicable.

Informed Consent Statement: Not applicable.

Data Availability Statement: The data presented in this study are available on request from the corresponding author.

Conflicts of Interest: The authors declare no conflict of interest.

\section{References}

1. Ledda, A.; Pindozzi, S.; Marcheggiani, E.; Cervelli, E.; De Montis, A.; Galli, A. The impact of collaboration on research about rural buildings and landscape: A case study in Italy. Land Use Policy 2020, 97, 104757. [CrossRef]

2. Serra, P.; Pons, X.; Sauri, D. Land-cover and land-use change in a Mediterranean landscape: A spatial analysis of driving forces integrating biophysical and human factors. Appl. Geogr. 2008, 28, 189-209. [CrossRef]

3. Mercuri, A.M. Genesis and evolution of the cultural landscape in central Mediterranean: The 'where, when and how' through the palynological approach. Landsc. Ecol. 2017, 29, 1799-1810. [CrossRef]

4. Blondel, J. The 'design' of Mediterranean landscapes: A millennial story of humans and ecological systems during the historic period. Hum. Ecol. 2006, 34, 713-729. [CrossRef]

5. Strollo, A.; Smiraglia, D.; Bruno, R.; Assennato, F.; Congedo, L.; De Fioravante, P.; Giuliani, C.; Marinosci, I.; Riitano, N.; Munafò, M. Land consumption in Italy. J. Maps 2020, 16, 113-123. [CrossRef]

6. Statuto, D.; Cillis, G.; Picuno, P. Analysis of the effects of agricultural land use change on rural environment and landscape through historical cartography and GIS tools. J. Agric. Eng. 2016, 47, 28-39. [CrossRef]

7. Malandra, F.; Vitali, A.; Urbinati, C.; Weisberg, P.J.; Garbarino, M. Patterns and drivers of forest landscape change in the Apennines range, Italy. Reg. Environ. Chang. 2019, 19, 1973-1985. [CrossRef]

8. Turner, B.L.; Meyer, W.B.; Skole, D.L. Global land-use land-cover change-Towards an integrated study. Ambio 1994, 23, 91-95. [CrossRef]

9. Altieri, M.A.; Nicholls, C.I. The adaptation and mitigation potential of traditional agriculture in a changing climate. Clim. Chang. 2013, 140, 33-45. [CrossRef]

10. Ledda, A.; Serra, V.; De Montis, A. The effect of rural buildings on landscape fragmentation in Natura 2000 sites: A case study in Sardinia. Sustainability 2019, 11, 4695. [CrossRef]

11. Santoro, A.; Venturi, M.; Piras, F.; Fiore, B.; Corrieri, F.; Agnoletti, M. Forest area changes in Cinque Terre National Park in the last 80 years. Consequences on landslides and forest fire risks. Land 2021, 10, 293. [CrossRef]

12. Strijker, D. Marginal lands in Europe-Causes of decline. Basic Appl. Ecol. 2005, 6, 99-106. [CrossRef]

13. Navarro, L.; Pereira, H.M. Rewilding abandoned landscapes in Europe. Ecosystems 2012, 15, 900-912. [CrossRef] 
14. Van Vliet, J.; de Groot, H.L.; Rietveld, P.; Verburg, P. Manifestations and underlying drivers of agricultural land use change in Europe. Landsc. Urban Plan. 2015, 133, 24-36. [CrossRef]

15. Garbarino, M.; Morresi, D.; Urbinati, C.; Malandra, F.; Motta, R.; Sibona, E.M.; Vitali, A.; Weisberg, P.J. Contrasting land use legacy effects on forest landscape dynamics in the Italian Alps and the Apennines. Landsc. Ecol. 2020, 35, 2679-2694. [CrossRef]

16. Cimini, D.; Tomao, A.; Mattioli, W.; Barbati, A.; Corona, P. Assessing impact of forest cover change dynamics on high nature value farmland in Mediterranean mountain landscape. ASR 2013, 37, 29-37. [CrossRef]

17. Debussche, M.; Lepart, J.; Dervieux, A. Mediterranean landscape changes: Evidence from old postcards. Glob. Ecol. Biogeogr. 1999, 8, 3-15. [CrossRef]

18. Macdonald, D.; Crabtree, J.R.; Wiesinger, G.; Dax, T.; Stamou, N.; Fleury, P.; Lazpita, J.; Gibon, A. Agricultural abandonment in mountain areas of Europe: Environmental consequences and policy response. J. Environ. Manag. 2000, 59, 47-69. [CrossRef]

19. Améztegui, A.; Brotons, L.; Coll, L. Land-use changes as major drivers of mountain pine (Pinus uncinata Ram.) expansion in the Pyrenees. Glob. Ecol. Biogeogr. 2010, 19, 632-641. [CrossRef]

20. Perpiña Castillo, C.; Kavalov, B.; Diogo, V.; Jacobs-Crisioni, C.; Batista e Silva, F.; Lavalle, C. Agricultural Land Abandonment in the EU within 2015-2030; JRC113718; European Commission: Brussels, Belgium, 2018.

21. Tattoni, C.; Ciolli, M.; Ferretti, F.; Cantiani, M. Monitoring spatial and temporal pattern of Paneveggio forest (northern Italy) from 1859 to 2006. iForest 2010, 3, 72-80. [CrossRef]

22. Assini, S.; Filipponi, F.; Zucca, F. Land cover changes in an abandoned agricultural land in the Northern Apennine (Italy) between 1954 and 2008: Spatio-temporal dynamics. Plant Biosyst. Int. J. Deal. All Asp. Plant Biol. 2014, 149, 807-817. [CrossRef]

23. Malandra, F.; Vitali, A.; Urbinati, C.; Garbarino, M. 70 years of land use/land cover changes in the Apennines (Italy): A metaAnalysis. Forests 2018, 9, 551. [CrossRef]

24. Gillespie, M.A.K.; Baude, M.; Biesmeijer, J.; Boatman, N.; Budge, G.E.; Crowe, A.; Memmott, J.; Morton, R.D.; Pietravalle, S.; Potts, S.G.; et al. A method for the objective selection of landscape-scale study regions and sites at the national level. Methods Ecol. Evol. 2017, 8, 1468-1476. [CrossRef]

25. Bielecka, E. GIS spatial analysis modeling for land use change. A bibliometric analysis of the intellectual base and trends. Geosciences 2020, 10, 421. [CrossRef]

26. Cillis, G.; Statuto, D.; Picuno, P. Integrating remote-sensed and historical geodata to assess interactions between rural buildings and agroforestry land. J. Environ. Eng. Landsc. Manag. 2021, 29, 229-243. [CrossRef]

27. Statuto, D.; Cillis, G.; Picuno, P. GIS-based analysis of temporal evolution of rural landscape: A case study in Southern Italy. Nat. Resour. Res. 2019, 28, 61-75. [CrossRef]

28. Modica, G.; Praticò, S.; Laudari, L.; Ledda, A.; Di Fazio, S.; De Montis, A. Implementation of multispecies ecological networks at the regional scale: Analysis and multi-temporal assessment. J. Environ. Manag. 2021, 289. [CrossRef] [PubMed]

29. Dai Prà, E. APSAT 9: Cartografia Storica e Paesaggi in Trentino: Approcci Geostorici; Società Archeologica Padana: Mantova, Italy, 2013.

30. Dai Prà, E. For a new applied historical geography: Prolegomena to a center for the study, the enhancement and the active fruition of historical cartography. Boll. Assoc. Ital. Cartogr. 2018, 162, 108-122.

31. Amici, V.; Maccherini, S.; Santi, E.; Torri, D.; Vergari, F.; Del Monte, M. Long-term patterns of change in a vanishing cultural landscape: A GIS-based assessment. Ecol. Inform. 2017, 37, 38-51. [CrossRef]

32. Brovelli, M.A.; Wu, H.; Minghini, M.; Molinari, M.E.; Kilsedar, C.E.; Zheng, X.; Shu, P.; Chen, J. Open source software and open educational material on land cover maps intercomparison and validation. ISPRS Int. Arch. Photogramm. Remote Sens. Spat. Inf. Sci. 2018, XLII-4, 61-68. [CrossRef]

33. Gizzi, F.T.; Proto, M.; Potenza, M.R. The Basilicata region (Southern Italy): A natural and 'human-built' open-air laboratory for manifold studies. Research trends over the last 24 years (1994-2017). Geomat. Nat. Hazards Risk 2019, 10, 433-464. [CrossRef]

34. Conte, A.L.; Di Pietro, R.; Iamonico, D.; Di Marzio, P.; Cillis, G.; Lucia, D.; Fortini, P. Oak decline in the Mediterranean basin: A study case from the southern Apennines (Italy). Plant Sociol. 2019, 56, 69-80.

35. Coluzzi, R.; Fascetti, S.; Imbrenda, V.; Italiano, S.S.P.; Ripullone, F.; Lanfredi, M. Exploring the use of sentinel-2 data to monitor heterogeneous effects of contextual drought and heatwaves on Mediterranean forests. Land 2020, 9, 325. [CrossRef]

36. Borghetti, M.; Moretti, N. Basilicata, terra di boschi e studi forestali. Forest 2020, 17, 1-16. [CrossRef]

37. Statuto, D.; Cillis, G.; Picuno, P. Visual quality indicators for assessing landscape characteristics and managing its protection. In Proceedings of the Public Recreation and Landscape Protection-With Sense Hand in Hand? Krrtiny, Czech Republic, 13-15 May 2019; pp. 476-480. Available online: https:/ / www.researchgate.net/publication/333192079_VISUAL_QUALITY_INDICATORS_ FOR_ASSESSING_LANDSCAPE_CHARACTERISTICS_AND_MANAGING_ITS_PROTECTION (accessed on 24 April 2021).

38. Picuno, P.; Cillis, G.; Statuto, D. Investigating the time evolution of a rural landscape: How historical maps may provide environmental information when processed using a GIS. Ecol. Eng. 2019, 139C, 105580. [CrossRef]

39. Basilicata Region. Sistemi Ambientali e Rete Natura 2000 della Regione Basilicata: Scoprire e Proteggere gli Ambienti Naturali e i Paesaggi Culturali della Lucania. 2015. Available online: http://www.retecologicabasilicata.it/ambiente/site/portal/section.jsp? sec $=109915$ (accessed on 22 June 2021).

40. Cillis, G.; Statuto, D.; Picuno, P. Historical maps processed into a GIS for the assessment of forest landscape dynamics. In Proceedings of the Public Recreation and Landscape Protection-With Sense Hand in Hand? Krtiny, Czech Republic, 13-15 May 2019; pp. 180-184. 
41. Cillis, G.; Statuto, D.; Picuno, P. A GIS-based approach to monitor and asses historical forest landscape evolution. In Proceedings of the Public Recreation and Landscape Protection-With Sense Hand in Hand! Conference, Krtiny, Czech Republic, 10-11 May 2021; pp. 16-20.

42. QGIS Development Team. QGIS Geographic Information System. Open Source Geospatial Foundation Project. 2021. Available online: http:/ / qgis.osgeo.org (accessed on 21 February 2021).

43. Loran, C.; Haegi, S.; Ginzler, C. Comparing historical and contemporary maps-A methodological framework for a cartographic map comparison applied to Swiss maps. Int. J. Geogr. Inf. Sci. 2018, 32, 2123-2139. [CrossRef]

44. Tichy, F. Die Wälder der Basilicata und die Entwaldung im 19. Jahrhundert. Vorgänge, Ursachen und Folgen; Keysersche Verlagsbuchhandlung: Heidelberg, Germany, 1962.

45. Statuto, D.; Cillis, G.; Picuno, P. Using historical maps within a GIS to analyze two centuries of rural landscape changes in Southern Italy. Land 2017, 6, 65. [CrossRef]

46. Ferretti, F.; Sboarina, C.; Tattoni, C.; Vitti, A.; Zatelli, P.; Geri, F.; Pompei, E.; Ciolli, M. The 1936 Italian Kingdom forest map reviewed: A dataset for landscape and ecological research. Ann. Silvic. Res. 2018, 42, 3-19.

47. European Union, Copernicus Land Monitoring Service 2021; European Environment Agency (EEA). Available online: https: / / land.copernicus.eu/pan-european/corine-land-cover (accessed on 15 January 2021).

48. GIMP Development Team. GIMP. Available online: https://www.gimp.org (accessed on 10 June 2021).

49. ISPRA. Carta della Natura. Available online: https://www.isprambiente.gov.it/it/servizi/sistema-carta-della-natura (accessed on 8 January 2021).

50. Peña-Angulo, D.; Khorchani, M.; Errea, P.; Lasanta, T.; Martínez-Arnáiz, M.; Nadal-Romero, E. Factors explaining the diversity of land cover in abandoned fields in a Mediterranean mountain area. CATENA 2019, 181. [CrossRef]

51. MATTM. Geopartale Nazionale. 2021. Available online: http://www.pcn.minambiente.it/mattm/ (accessed on 2 February 2021)

52. Stepinski, T.; Jasiewicz, J.; Hengl, T.; Evans, I.S.; Wilson, J.P.; Gould, M. Geomorphons-A new approach to classification of landform. In Proceedings of the Geomorphometry Conference, Redlands, CA, USA, 7-11 September 2011; pp. 109-112.

53. Jasiewicz, J.; Stepinski, T.F. Geomorphons-A pattern recognition approach to classification and mapping of landforms. Geomorphology 2013, 182, 147-156. [CrossRef]

54. Cuba, N. Research note: Sankey diagrams for visualizing land cover dynamics. Landsc. Urban Plan. 2015, 139, 163-167. [CrossRef]

55. Palmero-Iniesta, M.; Pino, J.; Pesquer, L.; Espelta, J.M. Recent forest area increase in Europe: Expanding and regenerating forests differ in their regional patterns, drivers and productivity trends. Eur. J. For. Res. 2021. [CrossRef]

56. FAO. Global Forest Resources Assessment 2020; Food and Agriculture Organization of the United Nations (FAO): Rome, Italy, 2020.

57. Endress, B.A.; Chinea, J.D. Landscape patterns of tropical forest recovery in the Republic of Palau. Biotropica 2001, 33, 555-565. [CrossRef]

58. García-Ruiz, J.; Lasanta, T.; Nadal-Romero, E.; Lana-Renault, N.; Álvarez-Farizo, B. Rewilding and restoring cultural landscapes in Mediterranean mountains: Opportunities and challenges. Land Use Policy 2019, 99. [CrossRef]

59. Geri, F.; Rocchini, D.; Chiarucci, A. Landscape metrics and topographical determinants of large-scale forest dynamics in a Mediterranean landscape. Landsc. Urban Plan. 2010, 95, 46-53. [CrossRef]

60. Chazdon, R.L.; Brancalion, P.H.S.; Laestadius, L.; Bennett-Curry, A.; Buckingham, K.; Kumar, C.; Moll-Rocek, J.; Vieira, I.C.G.; Wilson, S.J. When is a forest a forest? Forest concepts and definitions in the era of forest and landscape restoration. Ambio 2016, 45, 538-550. [CrossRef] [PubMed]

61. Marongiu, S.; Gismondi, R. Le problematiche delle statistiche forestali e le prospettive future. Un inquadramento delle indagini ISTAT nel nuovo PSN 2017-2019. L'Italia For. Mont. 2018, 73, 79-90. [CrossRef]

62. D’Amico, G.; Vangi, E.; Francini, S.; Giannetti, F.; Nicolaci, A.; Travaglini, D.; Massai, L.; Giambastiani, Y.; Terranova, C.; Chirici, G. Are we ready for a National Forest Information System? State of the art of forest maps and airborne laser scanning data availability in Italy. iForest 2021, 14, 144-154. [CrossRef]

63. Pindozzi, S.; Cervelli, E.; Capolupo, A.; Okello, C.; Boccia, L. Using historical maps to analyze two hundred years of land cover changes: Case study of Sorrento peninsula (south Italy). Cartogr. Geogr. Inf. Sci. 2016, 43, 250-265. [CrossRef]

64. Lelli, C.; Nascimbene, J.; Alberti, D.; Agostini, N.; Zoccola, A.; Piovesan, G.; Chiarucci, A. Long-term changes in Italian mountain forests detected by resurvey of historical vegetation data. J. Veg. Sci. 2020, 32, 1. [CrossRef]

65. Amici, V.; Santi, E.; Filibeck, G.; Diekmann, M.; Geri, F.; Landi, S.; Scoppola, A.; Chiarucci, A. Influence of secondary forest succession on plant diversity patterns in a Mediterranean landscape. J. Biogeogr. 2013, 40, 2335-2347. [CrossRef]

66. Henne, P.D.; Elkin, C.; Franke, J.; Colombaroli, D.; Calò, C.; La Mantia, T.; Pasta, S.; Conedera, M.; Dermody, O.; Tinner, W. Reviving extinct Mediterranean forest communities may improve ecosystem potential in a warmer future. Front. Ecol. Environ. 2015, 13, 356-362. [CrossRef]

67. Monaco, A.L.L.; Luziatelli, G.; Latterini, F.; Tavankar, F.; Picchio, R. Structure and dynamics of deadwood in pine and oak stands and their role in $\mathrm{CO}_{2}$ sequestration in lowland forests of Central Italy. Forests 2020, 11, 253. [CrossRef]

68. Lechner, A.M.; Foody, G.M.; Boyd, D.S. Applications in remote sensing to forest ecology and management. One Earth 2020, 2, 405-412. [CrossRef]

69. Recanatesi, F.; Giuliani, C.; Ripa, M.N. Monitoring Mediterranean oak decline in a peri-urban protected area using the NDVI and sentinel-2 images: The case study of Castelporziano State Natural Reserve. Sustainability 2018, 10, 3308. [CrossRef] 
70. Cillis, G.; Statuto, D.; Picuno, P. Vernacular farm buildings and rural landscape: A geospatial approach for their integrated management. Sustainability 2019, 12, 4. [CrossRef]

71. Ostafin, K.; Iwanowski, M.; Kozak, J.; Cacko, A.; Gimmi, U.; Kaim, D.; Psomas, A.; Ginzler, C.; Ostapowicz, K. Forest cover mask from historical topographic maps based on image processing. Geosci. Data J. 2017, 1, 29-39. [CrossRef]

72. Sobala, M. Do historical maps show the maximal anthropopressure in the Carpathians? J. Mt. Sci. 2021, 18. [CrossRef]

73. Cervelli, E.; Di Perta, E.S.; Pindozzi, S. Identification of marginal landscapes as support for sustainable development: GIS-based analysis and landscape metrics assessment in Southern Italy areas. Sustainability 2020, 12, 5400. [CrossRef]

74. Piras, F.; Venturi, M.; Corrieri, F.; Santoro, A.; Agnoletti, M. Forest surface changes and cultural values: The forests of Tuscany (Italy) in the last century. Forests 2021, 12, 531. [CrossRef] 